\title{
Anthropometric status, fasting blood sugar, nutrient intake and energy balance of traders in a market population in Nsukka, Nigeria
}

\author{
Onuoha NO, Okafor AM, Eme PE* and Onyia UD \\ Department of Home Science, Nutrition and Dietetics, University of Nigeria, Nsukka, Nigeria
}

\begin{abstract}
This study assessed the anthropometric status, fasting blood sugar, nutrient intake and energy balance of traders in a market population in Nsukka, Nigeria. Three hundred and ninety-one subjects selected out of every 13th stall in each line in the market were used for the study. Anthropometric measurements of weight and height were taken. Ten per cent of the sample size was used for biochemical (fasting blood glucose), dietary intake (macronutrients) measurements and energy expenditure estimation. Data obtained were analysed using the computer program Statistical Product and Service Solution (SPSS) for windows version 17. Overweight was significantly $(\mathrm{p}<0.05)$ more prevalent among the males $(42.2 \%)$ than females $(32.1 \%)$. Females $(17.0 \%, 5.3 \%$ and $0.9 \%)$ were significantly $(\mathrm{p}<0.05)$ more obese than the males $(9.2 \%, 3.5 \%$ and $0.6 \%)$. Diabetes mellitus was not observed among the subjects. Mean energy (2998.0 kcal males; $2784.0 \mathrm{kcal}$ females) intake of the subjects and mean fat intake for the male subjects $(99.0 \mathrm{~g}$ ) was above the recommended whereas mean carbohydrate (308.0 g males; $273.0 \mathrm{~g}$ females) intake of the subjects was below the recommended. Positive energy balance was observed among the subjects. Positive and significant $(\mathrm{p}<0.05)$ relationships existed between subjects physical activity level (PAL) and energy balance, energy intake and energy balance and energy intake and PAL of the subjects.
\end{abstract}

\section{Introduction}

Obesity is defined as a condition of abnormal or excess fat accumulation in adipose tissue to the extent that health may be impaired [1]. The prevalence of overweight and obesity is increasing and obesity is now estimated to be the second leading cause morbidity and mortality causing an estimated 2.6 million deaths worldwide and $2.3 \%$ of the global burden of disease [2]. Increase in body mass index are strongly associated with an increased risk of non-insulin dependent diabetes, especially when the obesity is centrally distributed [3].

Diabetes mellitus is a metabolic disorder characterized by raised plasma glucose levels [4]. Diabetes mellitus is a major health problem. It is now affecting many people in the workforce causing a major and deleterious impact on both individual and national productivity [5]. Its impact on health and economy is substantial [5]. Obesity, diet and sedentary lifestyle have been named as the major causative factors for the prevalence of the disease [6].

Epidemiological and other evidence suggest that regular exercise habits protect against the development of cardiovascular disease, and may also improve sense of well-being and protect against some complications of diabetes, lung disease and osteoporosis [7]. However, physical inactivity has become a public health problem all over the world [8]. The role of physical inactivity in the development of obesity has been well documented [9]. According to Awosan et al. [8] approximately 3.2 million deaths each year are attributable to insufficient physical activity.

Trading is one of the most popular activities in the informal sector of the economy of Nigerian cities [10]. One aspect of trading consists of the market traders who represent an important productive sector of the economy. These group of people are often neglected by the government in the area of welfare and health issues thereby making them to be risk of non-communicable diseases such as diabetes and hypertension. They have poor eating habits and low physical activity [10]. This study therefore assessed the anthropometric status, fasting blood sugar, nutrient intake and energy balance of traders in a market population in Nsukka, Nigeria.

\section{Materials and methods}

\section{Study area}

The study was conducted in Ogige market, in Nsukka Local Government Area, Enugu state. The total number of stalls in the market was 5234 with 5344 being the total population of traders in the market. Goods found there include cooked and raw food items, cooking utensils, clothing items, stationeries and furniture. The large number of activities carried out in Ogige market has made it a busy and highly populated place, due to the large number of traders and buyers.

\section{Subjects}

The subjects who participated in this study were 391 subjects. Every $13^{\text {th }}$ stall of each line in the market was selected to ensure that all the parts of the market were represented. All the participants signed a

Correspondence to: Eme PE, Department of Home Science, Nutrition and Dietetics, University of Nigeria, Nsukka, Nigeria, Tel: 08032889652; E-mail: paul.eze@unn.edu.ng

Key words: obesity, overweight, diabetes mellitus, energy balance

Received: October 20, 2016; Accepted: December 02, 2016; Published: December 06, 2016 
consent form and ethical approval was obtained from the Enugu State Ministry of Health. Ten percent of the sample size was used as the subsample population for biochemical (fasting blood glucose), dietary intake and energy expenditure assessment.

\section{Data collection}

Anthropometric measurements of weight and height of the subjects were taken. Body weight was measured with a bathroom scale (HANA model) and was recorded to the nearest $0.1 \mathrm{~kg}$. Height was measured using height metre and was recorded to the nearest $0.1 \mathrm{~cm}$. BMI, which is an index of weight for height was used to classify underweight, overweight and obesity among the subjects. BMI was classified using the WHO [11] standard.

Fasting blood glucose level was determined by finger-prick using an Accu-check glucometer with measuring range of 10-600 mg/dl (0.6-33.3 mmol/L). Impaired fasting blood glucose (FBG) and diabetes mellitus was classified as FBG of $100-125 \mathrm{mg} / \mathrm{dl}$ and $\geq 126 \mathrm{mg} / \mathrm{dl}$, respectively.

A 3-day weighed food record of the subjects was used to estimate the macro-nutrients (carbohydrate, protein and fat and energy) intake of the subjects. The energy and protein intake of the subjects was compared with the recommendations of Food and Agriculture Organization [FAO] [12] and WHO [13], respectively. Carbohydrate and fats intake were compared with WHO [14] recommendation.

A 3-day physical activity record of the subjects with time spent on each activity was obtained. This was used to calculate the physical activity level of the subjects and to determine their energy balance.

\section{Data analysis}

Data was analysed using the computer program Statistical Product and Service Solution (SPSS) for windows version 17. Data were presented in frequencies, percentages, means and cross-tabulations. Relationship between variables was obtained using chi-square, t-test and Pearson's correlations. $\mathrm{P}<0.05$ was accepted as the level of significance.

\section{Results}

Table 1 shows the socio-demographic data of the subjects. Less than half $(42.5 \%)$ of the subjects were within the age range of $18-28$ years while $3.8 \%$ were above 60 years. Males constituted $44.2 \%$ of the subjects while $55.8 \%$ of the subjects were females. Some (48.6\%) of the respondents were single and $45.5 \%$ were married.

Table 2 shows the mean weight, height and BMI of the subjects. The mean weight of the males $(76.2 \pm 11.4 \mathrm{~kg})$ were significantly $(\mathrm{p}<0.05)$ higher than that of the females $(71.2 \pm 14.5 \mathrm{~kg})$. Mean body mass index (BMI) for the male subjects was $25.9 \pm 3.0 \mathrm{~kg} / \mathrm{m}^{2}$ and $26.7 \pm 5.0 \mathrm{~kg} / \mathrm{m}^{2}$ for the females.

Table 3 shows the BMI of the subjects. A few of the female subjects (1.8\%) were underweight. Normal BMI was observed among $44.5 \%$ and $39.9 \%$ of the male and female subjects, respectively. Males (42.2\%) were significantly $(\mathrm{p}<0.05)$ more overweight than female subjects $(32.1 \%)$. Obese class I, II and III were significantly $(\mathrm{p}<0.05)$ more in the female $(17.0 \%, 5.3 \%$ and $0.9 \%)$ than male subjects $(9.2 \%, 3.5 \%$ and $0.6 \%)$. Overweight existed in $36.6 \%$ of the subjects whereas obese class I, II and III were observed in $13.6 \%, 6.1 \%$ and $0.8 \%$ of the subjects.

Table 4 shows the mean fasting blood glucose of the subjects by sex. Mean fasting blood glucose was $84.6 \pm 8.2 \mathrm{mg} / \mathrm{dl}$ for the males and
Table 1.Socio-demographic data of the subjects.

\begin{tabular}{|l|c|c|}
\hline \multicolumn{2}{|c|}{ Frequency } & Percentage \\
\hline Age (years) & 166 & 42.5 \\
\hline $18-28$ & 115 & 29.4 \\
\hline $29-39$ & 66 & 16.9 \\
\hline $40-50$ & 29 & 7.4 \\
\hline $50-60$ & 15 & 3.8 \\
\hline$>60$ & 391 & 100 \\
\hline Total & & \\
\hline Sex & 173 & 44.2 \\
\hline Male & 218 & 55.8 \\
\hline Female & 391 & 100 \\
\hline Total & & \\
\hline Marital status & 190 & 48.6 \\
\hline Single & 178 & 45.5 \\
\hline Married & 18 & 4.6 \\
\hline Widowed & 2 & 0.5 \\
\hline Divorced & 3 & 0.8 \\
\hline Separated & 391 & 100 \\
\hline Total & & \\
\hline & & \\
\hline
\end{tabular}

Table 2. Mean weight, height and BMI of the subjects by sex.

\begin{tabular}{|c|c|c|c|}
\hline Sex & Weight (kg) & Height (m) & Body mass index $\left(\mathrm{kg} / \mathrm{m}^{2}\right)$ \\
\hline Male & $76.2 \pm 11.4$ & $171.1 \pm 9.8$ & $25.9 \pm 3.0$ \\
\hline Female & $71.2 \pm 14.5$ & $162.9 \pm 6.5$ & $26.7 \pm 5.0$ \\
\hline Group mean & $73.4 \pm 13.4$ & $166.6 \pm 9.0$ & $26.5 \pm 4.3$ \\
\hline$t$ and p-values & $3.744,0.000$ & $9.934,0.000$ & $1.782,0.76$ \\
\hline \multicolumn{4}{|c|}{ Mean \pm standard deviation } \\
\hline
\end{tabular}

Table 3. Body mass index of the subjects by sex.

\begin{tabular}{|l|c|c|c|}
\hline Variables & $\begin{array}{c}\text { Male } \\
\text { N (\%) }\end{array}$ & $\begin{array}{c}\text { Female } \\
\text { N (\%) }\end{array}$ & $\begin{array}{c}\text { Total } \\
\text { N (\%) }\end{array}$ \\
\hline Body mass index (kg/m $\mathbf{~})$ & \multicolumn{3}{|l|}{} \\
\hline Under-weight $(\mathbf{< 1 8 . 5 )}$ & $0(0.0)$ & $4(1.8)$ & $4(1.0)$ \\
\hline Normal (18.5-24.9) & $77(44.5)$ & $87(39.9)$ & $164(41.9)$ \\
\hline 0verweight (25.0-29.9) & $73(42.2)$ & $70(32.1)$ & $143(36.6)$ \\
\hline Obese I (30.0-34.9) & $16(9.2)$ & $37(17.0)$ & $53(13.6)$ \\
\hline Obese II (35.0-40.0) & $6(3.5)$ & $18(5.3)$ & $24(6.1)$ \\
\hline 0bese III (>40.0) & $1(0.6)$ & $2(0.9)$ & $3(0.8)$ \\
\hline Total & $173(100.0)$ & $218(100.0)$ & $391(100.0)$ \\
\hline$\chi^{2}=14.451 ; \mathrm{df}=5 ; \mathrm{p}=0.013^{*}$ & & & \\
\hline *p $<0.05$ & & & \\
\hline
\end{tabular}

Table 4. Mean fasting blood glucose of the subjects by sex.

\begin{tabular}{|l|l|}
\hline Variables & Fasting blood glucose $\mathbf{( m g / d l )}$ \\
\hline Male & $84.6 \pm 8.2$ \\
\hline Female & $82.3 \pm 7.8$ \\
\hline Group mean & $83.2 \pm 8.1$ \\
\hline t and p values & $0.424,0.672$ \\
\hline
\end{tabular}

$82.3 \pm 7.8 \mathrm{mg} / \mathrm{dl}$ for females, respectively. Group mean fasting blood glucose among the subjects was $83.2 \pm 8.1 \mathrm{mg} / \mathrm{dl}$.

Table 5 shows the fasting blood glucose of the subjects by sex. Majority of the male subjects (100.0\%) and $95.0 \%$ of the female subjects had normal fasting blood glucose while $5.0 \%$ of the female subjects had impaired fasting blood glucose.

Table 6 shows the mean energy intake, mean energy expenditure and mean energy balance of the subjects by sex. The mean energy intakes of the male and female subjects were $2998.0 \pm 793.0 \mathrm{kcal}$ and $2784.0 \pm 1705.0 \mathrm{kcal}$, respectively. The male and female subjects had a 
Table 5. Fasting blood glucose level of the subjects by sex.

\begin{tabular}{|l|l|l|l|}
\hline Variables & $\begin{array}{l}\text { Male } \\
\text { N (\%) }\end{array}$ & $\begin{array}{l}\text { Female } \\
\text { N (\%) }\end{array}$ & $\begin{array}{l}\text { Total } \\
\text { N (\%) }\end{array}$ \\
\hline Fasting blood glucose (mg/dl) & \multicolumn{2}{|l|}{} \\
\hline Normal fasting blood glucose (<100) & $18(100.0)$ & $20(95.0)$ & $38(95.0)$ \\
\hline Impaired fasting glucose (100-125) & $0(0.0)$ & $1(5.0)$ & $1(5.0)$ \\
\hline Diabetes mellitus( $>\mathbf{1 2 6})$ & $0(0.0)$ & $0(0.0)$ & $0(0.0)$ \\
\hline Total & $18(100.0)$ & $21(100.0)$ & $39(100.0)$ \\
\hline $\mathrm{X}^{2}=0.273 ; \mathrm{df}=1 ; \mathrm{p}=0.602$ & & & \\
\hline Source:WHO, 2003 & & & \\
\hline
\end{tabular}

Table 6. Mean energy intake, energy expenditure and energy balance of the subjects by sex.

\begin{tabular}{|l|l|l|}
\hline & Male & Female \\
\hline Mean energy intake (kcal) & $2998.0 \pm 793.0$ & $2784.0 \pm 1705.0$ \\
\hline Mean energy expenditure (kcal) & $2555.0 \pm 688.0$ & $2161.0 \pm 982.0$ \\
\hline Mean energy balance (kcal) & $348.9 \pm 275.0$ & $539.3 \pm 359.0$ \\
\hline
\end{tabular}

Table 7. Mean energy and macro-nutrients intake of the subjects by sex.

\begin{tabular}{|l|l|l|l|l|}
\hline Sex & Energy (kcal) & $\begin{array}{l}\text { Protein (g) } \\
\mathbf{1 0 - 1 5 \%} \text { kcal }\end{array}$ & $\begin{array}{l}\text { Fat (g) } \\
\mathbf{1 5 - 3 0 \%} \text { kcal }\end{array}$ & $\begin{array}{l}\text { Carbohydrate (g) } \\
\mathbf{5 5} \text {-75 kcal }\end{array}$ \\
\hline Male & \multicolumn{5}{|l|}{} \\
\hline Mean intake (kcal) & $2998.0 \pm 793.0$ & $93.0 \pm 40.0$ & $99.0 \pm 78.0$ & $308.0 \pm 143.0$ \\
\hline RNI (kcal) & 2550.0 & $63.8-95.6$ & $42.5-85.0$ & $350.6-478.1$ \\
\hline Female & & & \\
\hline Mean intake (kcal) & $2784.0 \pm 1705.0$ & $55.0 \pm 46.0$ & $52.0 \pm 35.0$ & $273.0 \pm 144.0$ \\
\hline RNI (kcal) & 2100.0 & $52.5-78.8$ & $35-70.9$ & $288.8-393.8$ \\
\hline $\begin{array}{l}\text { Mean } \pm \text { standard deviationRNI= Recommended Nutrient Intake } \\
\text { Source of RNI: WHO (2003); protein requirements from WHO (2004); energy } \\
\text { requirements from FAO (2001) }\end{array}$ \\
\hline
\end{tabular}

Table 8. Energy balance of the subjects by sex.

\begin{tabular}{|l|l|l|l|}
\hline Energy balance & $\begin{array}{l}\text { Male } \\
\text { N (\%) }\end{array}$ & $\begin{array}{l}\text { Female } \\
\text { N (\%) }\end{array}$ & $\begin{array}{l}\text { Total } \\
\text { N (\%) }\end{array}$ \\
\hline Positive & $17(94.4)$ & $19(90.5)$ & $36(92.3)$ \\
\hline Negative & $1(5.6)$ & $2(9.5)$ & $39(7.7)$ \\
\hline Total & $18(100.0)$ & $21(100.0)$ & $39(100.0)$ \\
\hline & $\mathrm{X}^{2}=0.215$ & $\mathrm{df}=1$ & $\mathrm{p}=1$ \\
\hline
\end{tabular}

$2555.0 \pm 688.0 \mathrm{kcal}$ and $2161.0 \pm 982.0 \mathrm{kcal}$ mean energy expenditure, respectively. Mean energy balance of the male subjects was $348.9 \pm$ $275.0 \mathrm{kcal}$ and $539.3 \pm 359.0 \mathrm{kcal}$, respectively.

Table 7 shows the mean energy and macro-nutrients intake of the subjects by sex. The mean daily energy, protein, fat and carbohydrate intake of the male subjects were $2998.0 \pm 793.0 \mathrm{kcal}, 93.0 \pm 40.0 \mathrm{~g}, 99.0$ $\pm 78.0 \mathrm{~g}$ and $308.0 \pm 143.0 \mathrm{~g}$, respectively. Females had a mean daily intake of $2784.0 \pm 1705.0 \mathrm{kcal}$ for energy, $55.0 \pm 46.0 \mathrm{~g}$ for protein, 52.0 $\pm 35.0 \mathrm{~g}$ for fat and $273.0 \pm 144.0 \mathrm{~g}$ for carbohydrate.

Table 8 shows the energy balance of the subjects by sex. Majority of the subjects (92.3\%) had a positive energy balance. This was observed among $94.4 \%$ of the males and $90.5 \%$ of the female subjects. Negative energy balance was observed among $7.7 \%$ of the subjects (5.6\% males and $9.5 \%$ females).

Table 9 shows the relationship among BMI, energy and macronutrient intake, physical activity level and energy balance of the subjects. Positive and significant $(p<0.05)$ relationship existed between energy balance and body mass index, physical activity level and energy intake, energy balance and energy intake, and energy balance physical activity level.

\section{Discussion}

The prevalence of overweight (36.5\%) was higher than the $28.9 \%$
Table 9. Relationship among BMI, energy and macronutrient intake, physical activity level and energy balance of the subjects.

\begin{tabular}{|l|c|}
\hline Variables & p-value \\
\hline BMI and energy intake & 0.020 \\
\hline BMI and protein intake & 0.721 \\
\hline BMI and fat intake & 0.178 \\
\hline BMI and carbohydrate & 0.394 \\
\hline BMI and physical activity level & 0.113 \\
\hline BMI and energy balance & $0.004^{*}$ \\
\hline Energy intake and protein intake & 0.158 \\
\hline Energy intake and fat intake & 0.821 \\
\hline Energy intake and carbohydrate intake & 0.177 \\
\hline Energy intake and physical activity level & $0.000^{*}$ \\
\hline Energy intake and energy balance & $0.000^{*}$ \\
\hline Protein intake and fat intake & 0.363 \\
\hline Protein intake and carbohydrate intake & 0.087 \\
\hline Protein intake and physical activity level & 0.067 \\
\hline Protein intake and energy intake & 0.600 \\
\hline Fat intake and carbohydrate intake & 0.993 \\
\hline Fat intake and physical activity level & 0.825 \\
\hline Fat intake and energy balance & 0.991 \\
\hline Carbohydrate intake and physical activity level & 0.306 \\
\hline Carbohydrate intake and energy balance & 0.372 \\
\hline Physical activity level and energy balance & $0.005^{*}$ \\
\hline "Correlation is significant at p $<0.005$ & \\
\hline
\end{tabular}

reported by Awosan et al. [8] among traders in Sokoto central market, Sokoto Nigeria. Odugbemi, Onajole and Osibogun [15] reported a higher prevalence of overweight (39.9\%) among traders in Lagos. Overweight was significantly $(\mathrm{p}<0.05)$ more prevalent among the males $(42.0 \%)$ than females (32.1\%) similar to the findings of Awosan et al. [8] who reported a prevalence of $35.10 \%$ and $21.80 \%$ among male and female traders in Sokoto central market, Sokoto Nigeria. Overweight prevalence of $31.3 \%$ was reported among female traders in Ibadan Nigeria by Balogun and Owoaje [16]. Obesity prevalence of $20.4 \%$ was lower than the $28.1 \%$ prevalence reported by Awosan et al. [8] among traders in Sokoto central market, Sokoto Nigeria but was higher than the $12.3 \%$ prevalence of obesity reported by Odugbemi et al. [15] among traders in Lagos. The differences in the prevalence of overweight and obesity amongst the studied population can be attributed to the time and location when the studies were done. Females $(23.2 \%)$ were significantly $(\mathrm{p}<0.05)$ more obese than the males (13.3\%) indicating that they were more at cardiovascular risk. Awosan et al. [8] reported $41.90 \%$ and $15.80 \%$ obesity prevalence among female and male traders in Sokoto central market, Sokoto Nigeria. Balogun and Owoaje [16] reported $16.3 \%$ obesity prevalence among female traders in Ibadan Nigeria. Obesity predisposes individuals to a number of cardiovascular risks including hypertension, dyslipidaemia and coronary heart disease $[17,18]$. The potential medical consequences of obesity have been documented extensively particularly in relation to its common primary comorbidities such as cardiovascular diseases, type 2 diabetes mellitus and dyslipidaemia [19]. Findings of this study reveal that the risk of obesity comorbidities was mildly increased in $36.5 \%$, moderately increased in $13.5 \%$, severe in $6.1 \%$ and very severe in $0.8 \%$ of the subjects respectively.

Diabetes mellitus was not prevalent among the subjects whereas impaired fasting blood glucose was prevalent in $5 \%$ of the female subjects. Omorogiuwa, Ezenwanne, Osifor, Ozor and Ekhator [6] reported a $9.8 \%$ prevalence of diabetes mellitus among University staff in Ekpoma southern Nigeria. 
Mean energy intake (represented by the daily caloric intake) of the males $(2998.0 \pm 793.0 \mathrm{kcal})$ and females $(2784.0 \pm 1705.0 \mathrm{kcal})$ were above the recommended. In addition, the energy expended was less than the energy consumed leading to positive energy balance being observed among the subjects. Gradual accumulation of excess calories in the body is known to predispose one to obesity. Sedentary nature of trading as an occupation, however, may have contributed to the positive energy balance observed since most of the traders were physically inactive. According to WHO [20] the current high level of physical inactivity is believed to be partly due to insufficient participation in physical activity during leisure time and an increase in sedentary behaviour during occupational and domestic activities. Odugbemi et al. [15] reported $92 \%$ prevalence of physical inactivity among traders in Lagos. Several studies have shown that insufficient physical activity is one of the most important risk factors of obesity [21-23]. WHO [24] recommends that a total of one hour per day of moderate-intensity activity, such as walking on most days of the week, is probably needed to maintain a healthy body weight, particularly for people with sedentary occupations.

\section{Conclusion}

Overweight was more prevalent among the males than females whereas obesity was more prevalent among the females than males. Diabetes mellitus was not seen among the subjects. Majority of the subjects had a positive energy balance. Nutrition education is imminent for traders in order to tackle excess energy intake and for them to make informed food choices. Strategies to increase physical activity levels for traders in order to tackle overweight and obesity should be set up.

\section{References}

1. World Health Organization (2000) Obesity: preventing and managing the global epidemic. WHO Technical Report Series 894. Geneva: Switzerland.

2. Ezzati M, Martin H, Skjold S, vander Hoorn S, Murray CJ (2006) Trends in national and state level obesity in the USA after correction for self- report bias: analysis of health surveys. $J$ Royal Soc Med 99: 250-257.

3. Mahmood I, Khan MMR, Rahman MK, Chowdhury MMH (2009) A comparison of lipid profile between sedentary and non-sedentary workers. The Journal of Teachers Association RMC, Rajshahi 22: 10-14.

4. Akinloye OA, Adaramoye OA, Akinlade KS, Odetola AA, Raji AA (2007) Relationship between fasting plasma glucose and glycated haemoglobin in adult diabetic Nigerians. Afr J Biomed Res 10: 127-132.

5. Ekpenyong CE, Akpan UP, Nyebuk ED, John OI (2011) Detecting incident type 2 diabetes mellitus in south eastern Nigeria: the role of adiposity indices in relation to gender. J Diab Endocrin 2: 62-67.

6. Omorogiuwa A, Ezenwanne EB, Osifo C, Ozor MO, Ekhator CN (2009) Comparative study on risk factors for hypertension in a university setting in Southern Nigeria. Int $J$ Biomed Health Sci 5: 103-107.

7. Wielgosz AT (1993) The decline in cardiovascular health in developing countries. World Health Stat $Q$ 46: 90. [crossref]

8. Awosan KJ, Ibrahim MTO, Essien E, Yusuf AA, Okolo AC (2014) Dietary pattern, lifestyle, nutrition status and prevalence of hypertension among traders in Sokoto central market, Sokoto Nigeria. Int J Nutrition and Metabolism 6: 9-17.

9. DiPietro L (1995) Physical activity, body weight, and adiposity: an epidemiologic perspective. Exerc Sport Sci Rev 23: 275-303. [crossref]

10. Ogeah FN, Omofonmwan SI (2013) Urban markets as a source of employment generation in Benin city. Afr J Soc Sci 3: 62-78.

11. World Health Organization (2007) WHO Press release, WHO/63 2007.

12. Food and Agriculture Organization (2001) Human energy requirements. Report of a joint $\mathrm{FAO} / \mathrm{WHO} / \mathrm{UNU}$ expert consultation. Food and nutrition technical report series, FAO.

13. World Health Organization (2004) Protein and amino acid requirement in human nutrition. Report of a joint WHO/ FAO/UNU expert consultation. Geneva: Switzerland.

14. World Health Organization (2003) Diet, nutrition, and the prevention of chronic diseases. Report of a joint WHO/FAO expert consultation. WHO technical report series no 916. Geneva: Switzerland.

15. Odugbemi TO, Onajole AT, Osibogun AO (2012) Prevalence of cardiovascular risk factors amongst traders in an urban market in Lagos, Nigeria. Niger Postgrad Med J 19: 1-6. [Crossref]

16. Balogun MO, Owoaje ET (2007) Work conditions and health problems of female traders in Ibadan, Nigeria. Afr J Med Med Sci 36: 57-63. [Crossref]

17. Guh DP, Zhang W, Bansback N, Amarsi Z, Birmingham CL, et al. (2009) The incidence of co-morbidities related to obesity and overweight: a systematic review and metaanalysis. BioMed Central Public Health 9: 88.

18. Lavie CJ, Milani RV, Ventura HO (2009) Obesity and cardiovascular disease: risk factor, paradox, and impact of weight loss. J Am Coll Cardiol 53: 1925-1932. [Crossref]

19. Abidoye RO, Izunwa RD, Akinkuade, FO, Abidoye GO (2002) Interrelationships between lifestyle and diabetes mellitus, overweight/obesity and hypertension in Nigeria. Nutrition and Health 16: 203-213.

20. World Health Organization (2013b) Global strategy on diet, physical activity and health.WHO Fact Sheet. World Health Organization, Geneva, Switzerland.

21. Brock DW, Thomas O, Cowan CD, Allison DB, Gaesser GA, et al. (2009) Association between insufficiently physically active and the prevalence of obesity in the United States. J Physical Activity and Health 6: 1-5.

22. Baba R, Iwao N, Koketsu M, Nagashima M, Inasaka H (2006) Risk of obesity enhanced by poor physical activity in high school students. Pediatr Int 48: 268-273. [Crossref]

23. Yang X, Telama R, Leskinen E, Mansikkaniemi K, Viikari J, et al. (2007) Testing a model of physical activity and obesity tracking from youth to adulthood: the cardiovascular risk in young Finns study. Int J Obes (Lond) 31: 521-527. [Crossref]

24. World Health Report (2002) Reducing risks, promoting healthy life. World Health Organization, Geneva.

Copyright: (C2016 Onuoha NO. This is an open-access article distributed under the terms of the Creative Commons Attribution License, which permits unrestricted use, distribution, and reproduction in any medium, provided the original author and source are credited. 